\title{
The Effect of Using Lattice Method on Multiplication Achievement among Elementary Students
}

\author{
Anita Rebekawati \\ Department of Basic Education \\ Universitas Negeri Medan \\ North Sumatera, Indonesia \\ Corresponding email: anita.rebekawati@yahoo.com
}

\begin{abstract}
Some students face difficulties in calculating multidigit multiplication operation, moreover students only familiar with the certain method to solve multiplication operation. This study aimed to identify the effectiveness of Lattice Method on students' multiplication test score achievement. The research employs a quasi-experimental with non-equivalent pre-test and post-test control group design. This study involved the whole 6th grade students of Gracia Sustain Elementary School in the first semester of the school year 2017/2018. The samples were assigned into two groups: Class VI-B containing 27 students, representing the experimental group and Class VI-A containing 28 students, representing the control group. The experimental group students were taught using Lattice Method while the control group students were taught using the conventional method. Students' multiplication test score achievement was measured using posttest at the end of the intervention. Data were analyzed using independent-sample t-test. Independent samples t-test results showed that there was a significant difference in mean mathematical achievement between the experimental group $(M=$ 78.52, S.D. $=22.481)$ and the control group $(M=59.29$, S.D. $=$ 28.665) $; p=[0.008<0.05]$. These findings showed that the use of Lattice Method enhanced the students' multiplication test score achievement.
\end{abstract}

\section{Keywords_Lattice Method; multiplication learning}

\section{INTRODUCTION}

One of the key domains in primary school mathematics education is the domain of multiplication and division, or multiplicative reasoning. On the one hand, the importance of multiplicative reasoning lies in the fact that many situations encountered in daily life are of a multiplicative nature. One can think of, for example, situations in which amounts of ingredients for cooking for a certain number of persons have to be determined, or situations in which sweets have to be equally divided among a number of children. On the other hand, multiplicative reasoning is foundational for the understanding of many of the mathematical concepts that are met with in the later school career, such as ratio, fractions, and linear functions [1]. Mathematics is important not only academically but also important for our daily activities [2]. In addition, mathematics is integral to all areas of daily life; it affects successful functioning on the job, in school, at home, and in the community. Mathematics is crucial not only for success in school but in being an informed citizen, being productive and in personal fulfillment. Improving students' mathematics achievement has become a matter of increased focus in recent years. Mathematics learning needs calculation skills as its prerequisites skills which are used for solving the mathematical problems (mathematical operations) in daily life. Establishing good basic calculation skills makes all areas of mathematics easier and quicker to complete. Thus, calculation skills are the skills that students have to master in their mathematical learning process. There are four basic calculation skills on mathematical operations which are interrelated one another, mastering one mathematical operation will affect other operations too.

Mastering mathematical operation includes an understanding of the concept and skills to perform operations [3]. The skills of mathematical operations including addition, subtraction, multiplication, and division. Mathematics learning requires student mastering mathematical concepts that are interconnected and mutually sustainable. In mathematics there is a topic or concept of a prerequisite as a basis for understanding to the next topic or concept [4]. So to be able to master the subject of mathematics well, then the students must have well understood also to the previous concepts that become prerequisites of the concept of the subject being studied.

In relation to mathematics learning, calculation skills that students have to master are generally the basic math operations including addition (+), subtraction (-), multiplication (x), and division (:).Addition and subtraction are "referent preserving compositions", whereas multiplication and division are "referent transforming compositions". Multiplication operations are closely related to the addition operation while division operation is closely related to the subtraction operation. Multiplication is defined as repeated addition. Multiplication is a very rapid addition [5]. It is a skill that involves remembering basic math facts. While division is defined as a repeated subtraction. Multiplication is not as simple as repeated addition. Learning multiplication not only need addition skills but also need to master multiplication facts. Ability in memorizing the multiplication tables is a prerequisite one to be concerned before students do the multiplication operation. Multiplication is a skill that involves remembering basic math facts. Learning multiplication facts is a key issue in mathematics in primary schools [6]. It is difficult for students to solve mathematical problems that may require the skill of multiplication if they do not master the multiplication facts skills. Due to their weakness in mastering multiplication facts, 
they will lose interest, boredom, and lack of confidence in learning multiplication operations. One of the factors that influence the extent to which the acquisition of students multiplication operation skills is depended on the effectiveness of teaching methods. Accordingly, the method of teaching is one of the important factors that will affect mathematics achievement [7].

Therefore, teachers must constantly modify and enrich the range of teaching methods to entice students in improving the learning outcomes. Teaching methods need to be more focused on the active participation of students and attracted the attention of students to teaching and learning becomes more meaningful thus students will have the opportunity to explore, develop, evaluate and learn by constructivism. By using the attractive method of teaching the lessons, teachers can grab their students attention on their teaching. Ineffective teaching methods will limit the amount of input received by the student's lessons and so on will affect their math achievement. Therefore, the Lattice Method is applied by focusing on the active involvement of students in learning multiplication operation skills, especially for multi-digit multiplication. The writer emphasized that the Lattice Method, if properly instructed, could help students to overcome much difficulty in multiplication with whole numbers and decimals. Most importantly, students were able to do multiplication with the Lattice Method better than with the traditional way. Above all, this method improved self-esteem and self-confidence in the students for their academic learning.

\section{RESEARCH OBJECTIVES}

\section{A. The Purpose of the Study}

This study aimed to identify the effect of the Lattice Method on students' multiplication test score achievement.

\section{B. The Objective of the Study}

The objective of this study was to determine whether there was a difference in multiplication test score achievement between students who had received Lattice Method and students who had received Conventional Methods.

\section{Research Questions}

i. Are there significant differences in the mean scores of pre-test multiplication test score achievement among students between group received Lattice Method and Conventional Method?

ii. Are there significant differences in the mean scores of multiplication test score achievement among students those received Lattice Method between pre-test and post-test?

iii. Are there significant differences in the mean scores of multiplication test score achievement among students those received Conventional Method between pre-test and post-test?

iv. Are there significant differences in the mean scores of post-test multiplication test score achievement among students between group received Lattice Method and Conventional Method?

\section{Null Hypothesis}

Ho1: There are no significant differences in the mean scores of pre-test multiplication test score achievement among students between group received Lattice Method and Conventional Method.

Ho2: There are no significant differences in the mean scores of multiplication test score achievement for those students received Lattice Method between pre-test and posttest.

Ho3: There are no significant differences in the mean scores of multiplication test score achievement for those students received Conventional Method between pre-test and post-test.

Ho4: There are no significant differences in the mean scores of post-test multiplication test score achievement among students between group received Lattice Method and Conventional Method.

\section{METHOD}

This study has a quasi-experimental design with nonequivalent pre-test and post-test control group design which involves testing the hypothesis by using inferential statistics.

Table 1. Research Design

\begin{tabular}{|c|c|c|c|}
\hline & Pre-test & Treatment & Post-test \\
\hline Experimental Group (EG) & $\mathrm{O}$ & $\mathrm{X}_{1}$ & $\mathrm{O}_{1}$ \\
\hline Control Group (CG) & $\mathrm{O}$ & $\mathrm{X}_{2}$ & $\mathrm{O}_{2}$ \\
\hline
\end{tabular}

Note :

$\mathrm{O}$

$=$

$=$

$=$

$\mathrm{X} 2$

$\mathrm{O} 1=$

$\mathrm{O} 2=$
Pre-test Experimental Group (EG) / Control Group (CG).

Treatment with Lattice Method

Treatment with Conventional Method

Pre-test (O) was carried out on both the experimental group and control group, followed by treatment of the Lattice Method (X1) and Conventional Method (X2). After treatments X1 and $\mathrm{X} 2$ were given, respondents from both experimental group and conventional group answer the post-test (O1). Post-test was conducted to see whether there was a difference in multiplication test score achievement before and after the treatment was given. In the context of this study, Conventional Method was a usual teaching method which applied by the teachers, whereas Lattice Method is created by the researcher. Lattice Method is a method of multiplying large numbers using a grid. It is algorithmically equivalent to regular long multiplication, but the Lattice Method breaks the multiplication process into smaller steps, which some students find easier. Lattice method is a lot easier than the regular way and it is kind of fun too [8]. The pre-test and post-test were analyzed using ttest inferential statistics. The instruments were used in this study are pre-test and post-test. 


\section{ANALYSIS OF DATA}

At the analysis of data, the answer given to the scales by the students were evaluated by means of the statistical techniques such as mean, standard deviation, independent sample t-test and paired sample t-test using SPSS 22 statistical program.

\section{RESUltS}

Ho1: There are no significant differences in the mean scores of pre-test multiplication test score achievement among students between group received Lattice Method and Conventional Method.

To answer Ho1, means, standard deviations and significant value were computed for both experimental and control group on the pre-test achievement score. Table 2 shows these results

Table 2. Pre-test analysis for experimental group and control group

\begin{tabular}{ccccc}
\hline Group & $\begin{array}{c}\text { Number of } \\
\text { respondents }\end{array}$ & Mean & $\begin{array}{c}\text { Std. } \\
\text { Deviation }\end{array}$ & Significant \\
\hline Experimental & 27 & 51.85 & 30.639 & 0.560 \\
Control & 28 & 56.79 & 31.629 & \\
\hline
\end{tabular}

Table 2 above shows Ho1 was received at the significant level $\alpha=0.05$. Results showed that the mean scores of pre-test between experimental group and control group are not significant $(p=0.560>0.05)$. This means that there are no significant differences between mean score of multiplication test score achievement between group received Lattice Method $($ mean $=56.79$, S.D. $=31.629, \mathrm{n}=27)$ and group received Conventional Method $($ mean $=51.85$, S.D. $=30.639, \mathrm{n}=28)$ in the pre-test.

Ho2: There are no significant differences in the mean scores of multiplication test score achievement for those students received Lattice Method between pre-test and posttest.

To answer Ho2, means, standard deviations and significant value were computed for experimental group on the pretestposttest achievement test. Table 4 shows these results :

Table 3. Pre-test and post-test analysis for experimental group

\begin{tabular}{ccccc}
\hline Test & $\begin{array}{c}\text { Number of } \\
\text { respondents }\end{array}$ & Mean & $\begin{array}{c}\text { Std. } \\
\text { Deviation }\end{array}$ & Significant \\
\hline Pre-test & 27 & 51.85 & 30.639 & 0.000 \\
Post-test & 27 & 78.52 & 22.481 & \\
\hline
\end{tabular}

Results showed Ho2 was rejected at the significant level $\alpha$ $=0.05(\mathrm{p}=0.000<0.05)$. This means that there are significant differences in the mean scores of multiplication test score achievement for those students received Lattice Method between the pre-test $($ mean $=51.85$, S.D. $=30.639)$ and posttest $($ mean $=78.52$, S.D. $=22.481)$.

Ho3: There are no significant differences in the mean scores of multiplication test score achievement for those students received Conventional Method between pre-test and post-test.

To answer Ho3, means, standard deviations and significant value were computed for control group on the pretest-posttest achievement test. Table 3 shows these results :

Table 4. Pre-test and post-test analysis for control group

\begin{tabular}{ccccc}
\hline Test & $\begin{array}{c}\text { Number of } \\
\text { respondents }\end{array}$ & Mean & $\begin{array}{c}\text { Std. } \\
\text { Deviation }\end{array}$ & Significant \\
\hline Pre-test & 28 & 56.79 & 31.629 & 0.215 \\
Post-test & 28 & 59.29 & 28.665 & \\
\hline
\end{tabular}

Results showed Ho3 was received at significant level $\alpha=$ $0.05(\mathrm{p}=0.215>0.05)$. This means there are no significant differences between the mean score of multiplication test score achievement for those students received Conventional Method between the pre-test $($ mean $=56.79$, S.D. $=31.629)$ and posttest $($ mean $=59.29$, S.D. $=28.665)$.

Ho4: There are no significant differences in the mean scores of post-test multiplication test score achievement among students between group received Lattice Method and Conventional Method.

To answer Ho4, means, standard deviations and significant value were computed for both experimental and control group on the post-test achievement test. Table 5 shows these results :

Table 5. Post-test analysis for experimental group and control group

\begin{tabular}{ccccc}
\hline Group & $\begin{array}{c}\text { Number of } \\
\text { respondents }\end{array}$ & Mean & $\begin{array}{c}\text { Std. } \\
\text { Deviation }\end{array}$ & Significant \\
\hline Experimental & 27 & 78.52 & 22.481 & 0.008 \\
Control & 28 & 59.29 & 28.665 & \\
\hline
\end{tabular}

Table 5 above shows Ho4 was rejected at the significant level $\alpha=0.05$. Results showed that the mean scores of post-test between experimental group and control group are significant $(p=0.008<0.05)$. This means that there are differences between mean scores of multiplication test score achievement between group received Lattice Method (mean $=78.52$, S.D. $=$ 22.481, $\mathrm{n}=27$ ) and group received Conventional Method $($ mean $=59.29$, S.D. $=28.665, \mathrm{n}=28)$ in the post-test.

\section{CONCLUSIONS}

In a study of multiplication errors committed by students found that the majority of the errors were due to a lack of prerequisite skills. Errors in multiplication were primarily due to a lack of knowledge of multiplication facts and inadequate addition skills. This study examined the effect of Lattice Method using a quasi-experimental design. Lattice Method is a cool multiplication method for multiplying large numbers which is a lot easier than the regular way and it's kind of fun too.

The writer found that the Lattice Method was a quick and easy way to multiply more than two digit numbers. Students who had trouble multiplying with whole numbers and decimals by the traditional way. Therefore, they made a wide variety of mathematical errors in the traditional way. Students wrote 
entire product of each column without regrouping. They wrote tens value of each other subproduct and regrouped ones value into next column. They wrote one value of each subproduct, but didn't regroup tens value into next column. They added digits of multiplicands and multiplied. They misjudged computation signs. They did not use cross-multiplication and misplaced place value. These errors were the commonly made errors by students when they used the traditional way of multiplication with whole number and decimals. The writer emphasized that the Lattice Method, if properly instructed, could help students to overcome much difficulty in multiplication. Most obviously, students were able to do multiplication with the Lattice Method much better than with the traditional way.

The instruments are pre-test and post-test. A total of 55 students of 6 th grade were selected as respondents. The results found Lattice Method was effective in improving multiplication test score achievement. Thus, Lattice Method should be practiced widely in schools. These findings have implications for students, teachers and other researchers from aspects such as readiness, planning, and implementation of teaching and learning multiplication. Teachers need to apply various of teaching methods that are cool and fun too. This action is necessary for increasing mathematics achievement among students.

\section{REFERENCES}

[1] Vergnaud, G. (1983). Multiplicative structures. In R. Lesh \& M. Landau (Eds.), Acquisition of mathematics concepts and processes (pp. 127174). New York: Academic Press.

[2] Norasmah, O., \& Shuki, O. (2009). Kaedah pengajaran dan pembelajaran. In I. Noraini, \& O. Shuki (Eds.), Pengajaran dan pembelajaran: teori dan praktis (pp. 75-100). Bangi: Universiti Kebangsaan Malaysia.

[3] Sri Subarinah. (2006). Inovasi Pembelajaran Matematika Sekolah Dasar. Jakarta : Depdiknas.

[4] Suherman, Erman. (2003). Evaluasi Pembelajaran Matematika. Bandung: JICA UPI

[5] Steve Slavin. 2005. Konsep Dasar Matematika. Jakarta : Gunung Mulia.

[6] Gardella, F.J. (2009). Introducing difficult mathematics topic in the elementary classroom: A teacher's guide to initial lessons. New York: Routledge Taylor \& Francis Group.

[7] Copley, J. V. (2000). The young child and mathematics. Washington: National Association for the Education of Young Children.

[8] Thomas, Vicki (2005). "Lattice Multiplication". Learn NC. UNC School of Education. Retrieved 4 July 2014. 